\author{
May/2019 \\ Working Paper 19-11 \\ rcea.org/RePEc/pdf/wp19-11.pdf
}

\title{
Promise, Trust and Betrayal: Costs OF BREACHING AN IMPLICIT CONTRACT
}

\author{
Daniel Levy \\ Bar-Ilan University, Israel \\ Emory University, USA \\ RCEA \\ Andrew T. Young \\ Texas Tech University, USA
}

Copyright belongs to the author. Short sections of the text, not exceeding three paragraphs, can be used provided proper acknowledgement is given.

The Rimini Centre for Economic Analysis (RCEA) was established in March 2007. RCEA is a private, nonprofit organization dedicated to independent research in Applied and Theoretical Economics and related fields. RCEA organizes seminars and workshops, sponsors a general interest journal, the Review of Economic Analysis (REA), and organizes a biennial conference, the Rimini Conference in Economics and Finance (RCEF). Scientific work contributed by the RCEA Scholars is published in the RCEA Working Paper series.

The views expressed in this paper are those of the authors. No responsibility for them should be attributed to the Rimini Centre for Economic Analysis. 


\title{
Promise, Trust and Betrayal: Costs of Breaching an Implicit Contract*
}

\author{
Daniel Levy** \\ Department of Economics, Bar-Ilan University \\ Ramat-Gan 52900, ISRAEL, \\ Department of Economics, Emory University \\ Atlanta GA, 30322, USA, and \\ Rimini Center for Economic Analysis, ITALY \\ Daniel.Levy@biu.ac.il \\ Andrew T. Young \\ College of Business Administration \\ Texas Tech University \\ Lubbock, TX 79409, USA \\ A.T.Young@ttu.edu
}

Last Revision: May 26, 2019

JEL Codes: A14, E12, E31, K10, L14, L16, L66, M30, N80

Keywords: Implicit Contract, Cost of Breaching a Contract, Cost of Breaking a Contract, Invisible Handshake, Customer Market, Long-Term Relationship, Price Rigidity, Sticky Prices, Nickel Coke, Coca-Cola, Secret Formula

\footnotetext{
* We thank the seminar participants at the 2017 Italian Law and Economics Association annual conference (LUMSA, Rome), at the 2018 Economic History Association of Israel annual conference (Tel Aviv University), at the 2015 Israeli History and Law Association annual conference (Ben-Zvi Institute, Jerusalem), and at Bar-Ilan University, for comments and suggestions. In particular, we thank Alexander Stremitzer, Ansgar Wohlschlegel, Dror Goldberg, Igor Livshits, David Klein, Itamar Caspi, and Osnat Peled, for helpful comments and suggestions. We are grateful to Dan Schwarzfuchs and David Geffen for bringing to our attention a 1935 change in the Secret Formula, which we were unaware of. We rotate co-authorship. All errors are ours.
}

** Corresponding author: Daniel.Levy@biu.ac.il 


\title{
Promise, Trust and Betrayal: Costs of Breaching an Implicit Contract
}

\begin{abstract}
We study the cost of breaching an implicit contract in a goods market, building on a recent study that documented the presence of such a contract in the Coca-Cola market, in the US, during 18861959. The implicit contract promised a serving of Coca-Cola of a constant quality (the "real thing”), and of a constant quantity (6.5oz in a bottle or from the fountain), at a constant nominal price of 5\$. We offer two types of evidence. First, we document a case that occurred in 1930, where the Coca-Cola Company chose to incur a permanently higher marginal cost of production, instead of a one-time increase in the fixed cost, to prevent a quality adjustment of Coca-Cola, which would be considered a breach of the implicit contract. Second, we explore the consequences of the Company's 1985 decision to replace the original Coke with the "New Coke." Using the model of Exit, Voice, and Loyalty (Hirschman 1970), we argue that the unprecedented public outcry that followed the New Coke's introduction, was a response to the Company's breaching of the implicit contract. We document the direct and quantifiable costs of this implicit contract breach, and demonstrate that the indirect, although unquantifiable, costs in terms of lost customer goodwill were substantial.
\end{abstract}

JEL Codes: A14, E12, E31, K10, L14, L16, L66, M30, N80

Keywords: Implicit Contract, Cost of Breaching a Contract, Cost of Breaking a Contract, Invisible Handshake, Customer Market, Long-Term Relationship, Price Rigidity, Sticky Prices, Nickel Coke, Coca-Cola, Secret Formula 


\section{Introduction}

Okun (1981) offered implicit contract as a possible explanation for price rigidity. However, of the dozen or so theories of price rigidity, the implicit contract theory is the least explored in the context of goods markets. ${ }^{1}$ Because implicit contracts are just that - implicit - "hard” data on them are hard to come by.

Not surprisingly, therefore, most of the empirical evidence on implicit contracts in goods markets comes from interview studies, pioneered by Blinder $(1991,1994)$ and Blinder, et al. (1998). ${ }^{2}$ Aside from the interview studies, we were able to find only handful of empirical papers that study implicit contracts in goods markets (Anderson and Simester 2010, Verhelst and Van den Poel 2012, Helper and Henderson 2014, Gans, et al 2017, Young and Levy 2014). ${ }^{3}$

While little is known about the empirical significance of implicit contracts in goods markets, even less is known about the costs of breaching them. In this paper, we offer two types of empirical evidence of the nature and the magnitude of the cost of breaching an implicit contract in a goods market. We build on Young and Levy (2014) who document an implicit contract between the Coca-Cola Company and its consumers.

Young and Levy (2014) argue that the Coca-Cola implicit contract had two “clauses:” one involving price and the other involving quality. Regarding the former, the implicit contract was associated with remarkable nominal price rigidity. As Figure 1 shows, from 1886 and into the 1950s, the price of $6.5 \mathrm{oz}$. of Coca-Cola, in a bottle or at the fountain, was 5 $\$$ (Young and Levy, 2004). The quality clause involved the Company's promise to maintain the constancy of the

\footnotetext{
${ }^{1}$ For surveys of price rigidity theories, see Gordon (1981, 1990), Rotemberg (1987), Caplin (1993), Weiss (1993), Romer (1993), Willis (2003), Wolman (2007), Klenow and Malin (2011), and Leahy (2011).

${ }^{2}$ In the interviews, Blinder's team asked pricing managers to rank price rigidity theories by relevance for them. It turns out that of 12 theories of price rigidity, implicit contracts had the highest rate of acceptance (74\%) as being relevant. Furthermore, "fear of antagonizing customers" also topped the list of answers to the question: "Why don’t you change price more frequently?” As Blinder notes, the idea of antagonizing customers "is open to various interpretations and does not obviously correspond to any of our theories - though it does evoke implicit contracts.” Pricing managers in Canada and in some other countries also ranked longterm relationships with their customers as an important barrier to adjusting prices. This is true despite the fact that the questionnaires used varied from country to country in terms of the phrasing, word choice, and questions' length and order of appearance. Business cycle conditions also varied depending on the time that the different surveys were conducted. See Apel et al. (2005), Small and Yates (1999), Amirault, et al. (2004), Hall, et al. (1996, 2000), Fabiani, et al. (2005, 2007), Álvarez, et al. (2006), Dhyne, et al. 2006), Greenslade and Parker (2008), and Levy and Smets (2010). See also Carlton (1979, 1989).

${ }^{3}$ Anderson and Simester (2010) run a controlled field study and find that customers boycott a retailer, if a product they bought from him is later sold by the retailer at a lower price. Verhelst and Van den Poel (2012) use data from a European retailer and find that the concavity of demand increases with customer loyalty, consistent with the idea of implicit contracts. Helper and Henderson (2014) focus on the managerial failures of GM that brought to its bankruptcy in 2009, and find that GM, unlike Toyota and Honda, failed in establishing implicit contract with its suppliers and workers. Beard, et al (2015) use data on the complaints received by the FCC about telecommunication companies, and find that the more competitive markets are, the fewer are the complaints that consumers voice. Gans, et al (2017) find that the volume of tweets to major US airlines increases when the quality of their service, as measured by on-time performance, worsens.
} 
Secret Formula, referring to it as the "Real Thing.". While the nickel Coke met its demise in the wake of post-WWII inflation, the quality clause would not be breached until 1985 when the Secret Formula was abandoned and a reformulated "New Coke" was introduced. While the nickel Coke died a slow death, phasing out throughout the 1950s, the breach of the quality clause in 1985 - on a particular date, with an explicit announcement by the Company - represents a unique event in the wake of which we can observe the cost of breaching an implicit contract. ${ }^{4}$

In the case of New Coke, we have a good deal of information on why the Coca-Cola Company made the decision to abandon the original Coke; we also have knowledge of the differences between the original and new formulas. With this in mind, we document the research and development costs that the Company incurred to develop and test New Coke; also the direct losses incurred by Coca-Cola bottlers subsequent to New Coke’s introduction. These provide an estimate of the quantifiable costs of breaching the implicit contract. We use Hirschman's (1970) model of exit, voice, and loyalty, as a framework for analyzing the behavior of US consumers in the days that followed New Coke's introduction. We also document a wealth of "soft" data on the costs that the Company incurred in terms of goodwill lost. Even though these latter costs are hard to quantify, we argue that they clearly dwarf the quantifiable costs.

The second evidence comes from an earlier time-period when the Coca-Cola Company incurred significant costs to avoid breaching the quality clause of the implicit contract. In 1930, the Company faced a government-imposed regulation regarding the processing of coca leaf extract (the notorious “Merchandise No. 5”). To continue using coca leaves and thus maintain the integrity of the Secret Formula, the Company chose to incur a permanently higher marginal cost of production instead of a one-time increase in the fixed cost. This cost can be viewed as a lower bound of the perceived cost of breaching the quality clause of the implicit contract.

\footnotetext{
${ }^{4}$ The timeline included in Figure 2 shows numerous types of changes and shocks that the soft-drink industry in general, and the Coca-Cola market in particular, have experienced during the period 1886-1959. This further underscores the extraordinary rigidity of the Coca-Cola's nominal price. Levy and Young (2004) propose multiple contributing factors to the initial nominal price rigidity (that later became part of the implicit contract). First, the Coca-Cola Company signed an unusual contract with two Tennessee lawyers that gave them bottling rights to the drink that included purchasing syrup at a fixed nominal price in perpetuity. Second, once bottles became a large part of Coca-Cola sales, early- to mid-twentieth century vending machines represented a technological constraint, because most of them were nickel-only, which limited the price adjustment options. Lastly, internal documents suggest that Company executives believed that the use of a single coin to purchase the drink minimized the inconvenience cost (a type of transaction cost) incurred by consumers. Given a single coin constraint, the smallest viable nominal price increase was $100 \%$ (from a nickel to a dime). The Coca-Cola Company request, in 1953, to issue a $7 \frac{1}{2} \mathbb{C}$ coin, which would permit a 50\% increase in the price of Coca-Cola, was rejected by the US Treasury (Levy and Young, 2004, p. 786). Relatedly, Knotek $(2008,2011)$ models price convenience in terms of the small change that a transaction requires and documents its importance for price rigidity. Snir, et al. (2018) study an environment with a natural experiment created by an unusual regulatory setting, to explore possible reasons for the popularity of convenient prices.
} 
The paper is organized as follows. In section 2, we discuss the implicit contract theory as it applies to goods markets. A brief summary of the Young and Levy's (2014) account of the CocaCola implicit contract is provided in section 3. In section 4, we document evidence of the permanently higher marginal cost that the Coca-Cola Company chose to incur in 1930 to avoid a quality change. Then in section 5, we discuss the 1985 episode when the Company did choose to breach the quality clause by introducing New Coke. Within that discussion, we report the direct ex ante costs of R\&D and the ex post losses incurred by bottlers. In section 6 , we describe the market's response to the New Coke. In section 7, we discuss possible reasons for the Company's miscalculation in light of its remarkable brand loyalty. In section 8, we use Hirschman's (1970) model of exit, voice, and loyalty to assess and interpret consumer reactions to the Company's breach of the implicit contract and its subsequent reintroduction of the original drink ("CocaCola Classic”). We conclude in section 9.

\section{Implicit contract: the invisible handshake}

In the "invisible handshake” model with repeated transactions, an implicit contract is an unwritten, legally non-binding understanding by which all parties have incentives to preserve that understanding. The contract is self-enforcing and stays in effect as long as the two parties adhere to the terms of the understanding, continuing to behave as expected.

According to Okun (1981), under an implicit contract sellers and buyers can settle for some acceptable and fair selling price at which the extra cost of more search exceeds its benefit. The stable price discourages buyers from searching because of the implicit commitment of the seller not to raise the price when markets are tight. In return, sellers do not cut the prices when there is insufficient demand. The implicit contract, therefore, helps sellers establish a long-term relationship with buyers by winning their loyalty through stable prices. Another advantage of stable prices is that they make future sales more predictable. ${ }^{5}$

\footnotetext{
${ }^{5}$ As discussed in Young and Levy (2014), implicit contracts can offer additional benefits to sellers and buyers. First, studies have shown that consumers value the guarantee of a fair price (Kahneman, et al. 1986, Ball and Romer 2003, Rotemberg 2005 and 2011). Indeed, there is experimental evidence that buyers often boycott, against their self-interest, sellers that appear to make unfair price increases (Fehr and Gächter 2000, Gächter and Herrmann 2009, Tyran and Engelmann 2005, Anderson and Simester 2010). Implicit contracts may also lessen time inconsistency problems in case of habit-forming goods (Nakamura and Steinsson 2011, Bils 1989). As discussed in Young and Levy (2014, pp. 812-813), this was particularly relevant in the case of Coca-Cola in light of its caffeine, and undetectable amounts of cocaine contents, whose habit-forming properties were well-known from the early days of Coca-Cola. Implicit contracts can potentially strengthen brand loyalty and reputation (Telser 1964 and 1980 , Klein and Leffler 1981, Shapiro 1983, Cabral 2000). A firm's goodwill and brand may insure consumers against pass-through of input cost fluctuations, and an implicit contract offers a credible commitment mechanism through which a firm can deliberately make itself vulnerable to consumer backlash if pass-through occurs (Godley 2013). Gottfries (1991) offers implicit contracts as a
} 
In the context of goods markets, much of the implicit contract literature is rooted in Okun's (1981) analysis, and emphasizes the role of a stable price as the key component of an implicit contract. ${ }^{6}$ However, there is potentially another, less explored component to an implicit contract: the quality of the product or the service.

In recent years, there have been several widely publicized episodes of quality adjustment that led to public protests; here we note just a few of them. In November 2015 the New York Times reported that Campbell had decided to change its chicken noddle soup recipe. ${ }^{7}$ Around the same time, consumers of Cadbury "Fruit and Nut" chocolate bars noticed that the recipe had been changed for the first time in 90 years by using sultanas instead of raisins. ${ }^{8}$ In November 2016, Toblerone's maker altered the shape of its chocolate bar by making the triangles narrower and by increasing the gap between the peaks. ${ }^{9}$ On August 15, 2017, Nestlé announced that it was removing nuts from its popular "Walnut Whips.” ${ }^{10}$ Most recently, in November 2017 it was reported that Nutella' manufacturer secretly altered the popular spread's ingredients, increasing the amount of sugar and fat, and reducing the amount of hazelnuts. ${ }^{11}$ As the footnoted sources attest to, in each of these cases consumers reacted with anger and disappointment through various social media outlets (Facebook, Twitter, etc.). However, those reactions pale in comparison to those of US consumers in 1985 when they learned that a reformulated New Coke would replace their beloved old Coca-Cola. The extent and the magnitude of that public outcry were extraordinary, as we demonstrate below.

possible explanation to why prices don't necessarily increase in the short run in response to increases in demand. Söderberg (2011) studies the effect of customer markets on inflation dynamics and the optimal conduct of monetary policy. The existence of meaningful implicit contracts can be formalized in infinite period games where reciprocity is maintained based on a fear of punishment (Baker, et al. 2002, Levin 2003). Note the difference between implicit contracts in labor markets and implicit contracts in goods markets. Implicit contracts in labor markets typically protect two-sided relationship-specific investments. Implicit contracts in goods markets, in contrast, need to protect only the relationship-specific investment of the consumer. ${ }^{6}$ See Phelps and Winter (1970), Blinder (1991, 1994), Blinder et al. (1998), Small and Yates (1999), Amirault, et al. (2004), Hall, et al. (1996, 2000), Fabiani, et al. (2005), Álvarez, et al. (2006), Dhyne, et al. 2006), Greenslade and Parker (2008), Anderson and Simester (2010), Levy and Smets (2010), and Paciello et al. (2019).

${ }^{7}$ Source: Stephanie Strom, “Campbell rethinks its recipe as consumer tastes change,” The New York Times, November 11, 2015, p. 16, https://www.nytimes.com/2015/11/10/business/campbell-rethinks-its-recipe-as-consumer-tastes-change.html? r=0, accessed December 7, 2017.

${ }^{8}$ Source: Rebecca Smithers, “Choc horror over Cadbury's Fruit and Nut recipe change,” The Guardian, November 4, 2015, https://www.theguardian.com/lifeandstyle/2015/nov/04/cadbury-fruit-and-nut-recipe-change-sultanas-raisins, accessed December 6, 2017.

${ }^{9}$ Source: Hannah Olivennes, “Toblerone Alters Shape of 2 Chocolate Bars, and Fans Are Outraged,” The New York Times, November 9, 2016, p. A11, https://www.nytimes.com/2016/11/09/world/europe/toblerone-triangle-change-uk.html?_r=0, accessed December 6, 2017.

${ }^{10}$ Source: Helena Horton, "Walnot Whip: Nestlé removes nut from new Walnut Whips after ingredient price surge,” The Telegraph, August 16, 2017, http://www.telegraph.co.uk/news/2017/08/16/walnot-whip-nestle-removes-nut-new-walnutwhips-ingredient-price/, accessed December 6, 2017.

${ }^{11}$ Source: "Nutella's apparently changed its ingredients and Twitter is furious," BBC, November 10, 2017 , http://www.bbc.co.uk/bbcthree/item/e06d5d6a-bc97-4d22-9045-06183f12089f, accessed December 6, 2017. 


\section{Implicit contract in the case of Coca-Cola}

Young and Levy (2014) discuss why Coca-Cola was a good candidate for an implicit contract. They argue that (a) Coca-Cola was potentially habit-forming, (b) its input costs were relatively volatile, and (c) it had numerous, close substitutes while its distinctive characteristics could be difficult to observe. For a good characterized by (a) and (b), an implicit contract can mitigate time consistency problems. The seller of the good may attract consumers by promising a continuation of the current price; yet when the future arrives, the seller may have an incentive to renege on that promise, for example, because of changes in input prices (Nakamura and Steinsson, 2011). Especially with a habit forming good, consumers may recognize this dynamic inconsistency and avoid being "hooked" and subject to future price changes. A contract is an obvious and straightforward device to mitigate this time consistency problem, but explicitly contracting on future prices with individual consumers may be prohibitively costly. It may, therefore, behoove the seller to attempt to foster an implicit contract. This will especially be true if, (c), the seller recognizes that consumers have good exit options.

Young and Levy (2014) argue that the Coca Cola Company developed business strategies that acknowledged the sort of consumer concerns described above. The Company aggressively marketed the $5 \$$ price, held the price of its syrup to bottlers and fountains constant, and provided negative and positive incentives to retailers to maintain the nickel Coke (Levy and Young, 2004). ${ }^{12}$ All of these measures insured consumers against future price volatility. On the quality side, the Company standardized the drink and cultivated the idea of the Secret Formula with its consumers; it strove to convince them that Coca-Cola was a distinct good without close substitutes; that consumers should insist upon the "real thing." Long-time (1923 to 1954) CocaCola Company president, Robert Woodruff, was so convinced of the Secret Formula’s importance to consumers that he would "prefer not to do anything of the kind [i.e., change the formula], except as a matter of life and death.”13

These understandings led to a gradual formation of an implicit contract between the Coca-

\footnotetext{
12 The Coca-Cola Company had no explicit control over the retail price of the soft drink, nor the price at which independent bottlers sold to retailers. (The Company did begin buying independent bottlers up in 1923.)

${ }^{13}$ Source: Robert W. Woodruff in a letter to Arthur Acklin, October 2, 1942, Robert W. Woodruff Papers, Special Collections Section, Emory University Library, Atlanta, GA. According to Allen (1994), Woodruff was concerned also about the possibility that changes in the Secret Formula, could be interpreted by consumers as an indicator that the Company was cutting corners by lowering its standards, if they found out. Therefore, "Woodruff decided to adopt a policy that there would never again be a change in the formula, no matter what” (Allen, 1994, p. 161).
} 
Cola Company and its customers. To demonstrate the establishment of the implicit contract, Young and Levy (2014) focus on observable implications of implicit contracts. For example, they demonstrate that the Company communicated its pledge not to raise the nickel price and not to change the Secret Formula; it made a commitment to continue selling the "Real Thing” for 5 to everyone and everywhere. ${ }^{14}$

Young and Levy (2014) also document the Company's efforts to communicate this pledge and its profitability to the retailers, which was important as the Company had no direct control on the retail price. Importantly, they demonstrate that the Company perceived itself as vulnerable to costly backlash in terms of lost goodwill if it reneged on its pledge. This aspect of the implicit contract was critical for ensuring its self-enforcement based on incentive compatibility. Unlike the nickel Coke, the Coca-Cola Company’s commitment to the "real thing” and its Secret Formula persisted right up until the introduction of New Coke in 1985. During a period of 74 years, Levy and Young (2014, pp. 807-809) report only eight instances of ingredient changes. Six of these changes were either legally mandated, or are best interpreted as attempts to maintain quality. ${ }^{15}$

\footnotetext{
${ }^{14}$ As far as we know, the Company never discussed explicitly the Secret Formula in its ads or in any other promotional information and materials. Instead, it emphasized "the real thing," contrasting it with hundreds of fake imitations that were continuously flooding the market. The cult-like admiration for the Secret Formula, and many urban legends associated with it and with its secrecy, are widespread. (For example, "It is well-known that only three people in the world know the Secret Formula. But a more surprising fact is that even in the most remote parts of Africa people know that only three people know the Secret Formula.”). The Company's reference to the Secret Formula by calling it "the real thing” was quite subtle, yet very systematic and effective way of further strengthening the popular beliefs in these urban legends. The Formula's apparent secrecy seem to have played an important role in this process. According to Allen (1994), "Woodruff's attitude toward the formula was more than just a matter of careful stewardship of one of the most valuable trade secrets in American business. He gloried in the process of secrecy itself, setting up elaborate procedures that seemed to be designed to call attention to the formula as much as they were to protect it. At Woodruff's direction, the company established a rule that no one could see the formula without the formal permission of the board, and then only in the presence of the Chairman, President, or corporate secretary. Furthermore, the rule said, only two company officials would be allowed to know the formula at any given time, and their identities were never to be disclosed for any reason. The company then publicized the policy. Over time, Woodruff's dramatic, cloak-and-dagger treatment of the formula had the effect of elevating it to the status of a cult object. During the era of air travel, the company's policy was amended to forbid the two officials who knew the formula from flying on the same plane; that rule, too, was widely broadcast. The existence of the most mysterious of the ingredients, the blend of flavoring oils called Merchandise No. 7X, was teasingly admitted — even while its composition was guarded as carefully as a state secret” (p. 162).

15 The first change was an addition of glycerin in 1889, to prevent the syrup from turning rancid. The second change occurred in 1899, when the Company decided to prepare two slightly different syrups — one for fountains and one for bottles - to ensure that the drink had the same taste in both contexts. The third change was imposed exogenously by regulators as a result of a lawsuit in 1901 (“cocaine lawsuit 1"), when the Company president admitted under oath that Coca-Cola had "a very small trace” of cocaine. The Company was forced to outsource the preparation of "Merchandise No. 5" (containing coca leaf and kola nut extracts) to remove the cocaine completely. The fourth change was made in 1904, when the Company switched from powdered sugar, which carried moisture and tended to sour, to granulated sugar. Consumers never noticed this change. The fifth change was also imposed exogenously as a result of a 1909 lawsuit (“cocaine lawsuit 2"), claiming that Coca-Cola was "misbranded” because its name promised kola and coca but contained little of either, and that it was "adulterated" by added caffeine. In April 1918, the company agreed to a settlement, which included a reduction in caffeine content by almost two-thirds. The sixth change occurred during WW I, when the company switched from cane sugar (which was in severe shortage and rationed), to a beet sugar, without affecting the Coca-Cola's flavor (Schaeffer and Bateman, 1985). Levy and Young (2014) offer more details on these changes in the secret formula, and the relevant references.
} 
There appear to have been only two true quality changes, both minor, over nearly three quarters of a century. The first change occurred in 1935 when a Rabbi by the name of Tobias Geffen convinced the Coca Cola Company to replace the original glycerin (produced from nonkosher beef tallow) to Proctor and Gamble’s vegetable based glycerin (produced from cottonseed and coconut oil). There is no evidence that the public ever became aware of this change and, therefore, it appears to have been a very minor one. ${ }^{16}$ The second change was a temporary use of saccharine and a decrease in the amount of caffeine and coca leaves in 1942. Not only was this change temporary; it was also undertaken during shortages associated with WWII rationing. Moreover, the public never became aware of this change while it was in effect. Therefore, in light of the Coca-Cola Company’s conservative history of quality adjustments, the explicit introduction (with much ill-fated fanfare) of the New Coke in 1985 represents a singular and dramatic quality change.

To summarize, Young and Levy (2014) show that Coca Cola's attributes and market structure made it a suitable candidate for an implicit contract with the Coca-Cola Company's consumers. They focus on the observable implications of such a contract, and provide evidence of the Company both acknowledging and acting on this implicit contract, which was valued by consumers. Moreover, they demonstrate that the Coca-Cola Company perceived itself as vulnerable to consumer backlash if it reneged on the pledge, concluding that the perceived costs of breaching the implicit contract were large. They, however, offer no evidence on the actual costs of breaching the implicit contract. In this paper, we set out to do exactly that. Specifically, we offer two types of evidence on the cost of breaching an implicit contract.

\section{Cost of averting a breach of the implicit contract}

The first evidence we offer is indirect. It is based on the way the Coca-Cola Company handled

\footnotetext{
${ }^{16}$ We learned about this change through a private correspondence from Dan Schwarzfuchs and David Geffen, after our 2014 paper was published. Two additional changes that were made in the Secret Formula following Rabbi Geffen's inquiry was the elimination of the tiny amount of alcohol, a by-product of wheat, which is forbidden for Passover, and a replacement of HFCS (High Fructose Corn Syrup), which is also not kosher-for-Passover, with cane sugar. These two changes in the Secret Formula, however, are only implemented for a two-week period each year, during the Passover holiday, in markets with significant observant Jewish communities. The bottles of Coca-Cola kosher-for-Passover are easy to spot thanks to their yellow caps. For details see Horowitz (2016), Samuel Freedman, “A Passover Toast to a Rabbi Known for Social Activism, and for Kosher CocaCola,” The New York Times (New York edition), April 23, 2011, p. A15

(http://www.nytimes.com/2011/04/23/us/23religion.html?_r=0, accessed December 26, 2017), Gail Lichtman, "The Coca-Cola Rabbi,” Jerusalem Post, February 19, 2010 (http://www.jpost.com/Jewish-World/Jewish-Features/The-Coca-Cola-rabbi, accessed December 26, 2017), Paul Lukas, “Kosher-for-Passover Coke: It’s Not Just for Jews Anymore,” New Republic Magazine, March 25, 2013 (https://newrepublic.com/article/112747/112747, accessed January 30, 2018), and http://www.jewishvirtuallibrary.org/the-kashering-of-coca-cola, accessed December 26, 2017.
} 
a shortage of coca leaves in 1929. We document that to avert a change in the drink's quality by changing the Secret Formula, which would have constituted a breach in the implicit contract and a one-time fixed cost, the Coca-Cola Company instead chose to pay a higher marginal cost indefinitely.

The shortage of coca leaves was related to government-imposed restrictions on the importation of coca leaves. As discussed in Levy and Young (2004), coca leaves' extract was one of the key components in "Merchandise No. 5" of the Secret Formula. US narcotics laws prohibited any importation of coca leaves except by two companies, Maywood and Merk \& Company; they were permitted to import the leaves and to manufacture cocaine for medical and scientific purposes. Coca-Cola was buying coca leaves extract from these companies, after they had filtered the cocaine out.

Given the continuous increase in the demand for Coca-Cola, by the end of the 1920s, the two companies were unable to manufacture enough coca leave extract to meet the Coca-Cola Company’s needs. The Coca-Cola Company, therefore, began lobbying in Washington, which lead to the introduction of an amendment to the proposed 1930 Porter Bill. The Porter Bill was designed to further toughen US narcotics laws. The amendment "was plainly aimed at rescuing the Coca-Cola Company” (Allen, 1994, p. 195) and initially encountered resistance:

"But giving up would mean changing the Secret Formula, and that was unacceptable. [...] Coca-Cola without the coca was unthinkable, even if the coca in question was a tiny dollop that was powdered, percolated, steamed, double-distilled, pasteurized, and otherwise exhausted until not one consumer in a million would have noticed its absence. The point was Coca Cola's mystique, the cult of the formula. If word got out that the coca was gone, people might think they tasted a difference, and that could be ruinous [emphasis in original]” (Allen, 1994, p. 196).

In the end, both houses of Congress signed off on the amendment, provided that the CocaCola Company would destroy any cocaine and other byproduct alkaloids under the supervision of the newly established Bureau of Narcotics, and made it part of federal law, leading to a resumption of a steady supply of coca leaves for the Company. ${ }^{17}$

\footnotetext{
${ }^{17}$ These bills and their public policy implications were discussed extensively by the US medical community. For example, the Journal of the American Medical Association (JAMA) has run a series of editorials analyzing and discussing these implications. See, “A Federal Narcotic Dictator," Journal of the American Medical Association 94(6), February 8, 1930, 412-413, “Another Porter Narcotic Bill," Journal of the American Medical Association 94(14), April 5, 1930, 1069-1070, and "Congress Amends Porter Narcotic Bill," Journal of the American Medical Association 94(24), June 14, 1930, p. 1922. The second of these JAMA
} 
Harrison Jones [Coca-Cola Company’s Vice President for Sales], in consultation with William P. Heath [Coca-Cola Vice President for Quality Control] and John A. Sibley [Associate General Counsel of Coca-Cola], did some calculations to assess the effect of the new taxes and the additional processing costs of the coca leaves, on the cost of manufacturing Merchandise No. $5 .^{18}$ These costs included, the cost of coca leaves (20థ/Lb in Peru), 10 $\$$ /Lb duty, 16 $/$ Lb narcotic tax, 50\$/oz for coca leave processing, cost of destroying cocaine (“unknown”), and the cost of freight of coca leaves from Peru to New York (also “unknown”). According to his calculations, which he conveyed to Woodruff in a memo on July 28, 1930, these additional taxes and coca leave processing costs would increase the cost of manufacturing Merchandise No. 5 from $\$ 1.11 / \mathrm{Lb}$ to $\$ 1.51 / \mathrm{Lb}$, a 36 percent increase. ${ }^{19,} 20$

Thus, the Company avoided adjusting quality by incurring a higher marginal cost of production. Furthermore, its lobbying efforts to secure continued supply of coca leaves were no doubt costly. The Company was willing to incur the costs associated with those efforts, plus the expected present value of the higher marginal cost to be incurred for each pound of Merchandise No. 5 indefinitely into the future. Given that willingness, these costs can be interpreted as a lower bound on the true perceived fixed cost of making a quality adjustment and breaching the implicit contract.

To assess the magnitude of these costs, we computed the annual added cost of producing Merchandise No. 5 that the Company incurred, ex post, as a result of these changes. The resulting figures are reported in Table 1. In 2018 prices, the added annual cost the company incurred amounted to \$1.4 million-\$3.1 million, between the years 1931-1939. As a proportion

editorials, dated April 5, 1930, notes: “On March 26, Representative Porter introduced a third narcotic bill, H.R. 11143, to create in the Treasury Department a bureau of narcotics and to remove existing limitations on the importation of coca leaves that do not contain cocaine or ecgonine and of certain salts, derivatives and preparations of coca leaves.” The H.R. 11143 bill replaced the previous two bills, and thus became known as the "Porter Bill” (Editorial of California and Western Medicine, July 1930, p. 515). Harrison Narcotics Act of 1914, which made cocaine use illegal in the US, had a similar provision. According to Pendergrast (1993, p. 448), “After intensive lobbying, Coca-Cola succeeded in having a loophole written into that law, allowing the importation of coca leaves if they were de-cocainized under government supervision.” See, "The Harrison Narcotic Act," Virginia Law Review 6(7), 1920, 534-540.

${ }^{18}$ Pendergrast (1993, p. 422) contains the original version of the Secret Formula, which according to his account, was in use in the 1930s and 1940s. The Formula, lists all the ingredients and corresponding quantities, including the extracts of Coca plant (labeled “F.E. Coco," i.e., Fluid Extract of Coca plant) and Cola nut (labeled "Citrate Caffeine”). These two ingredients combined, form what is known as Merchandise No. 5 in the Coca-Cola Company's internal jargon.

${ }^{19}$ Source: Memorandum from Harrison Jones to R.W. Woodruff, “In RE: \#5,” July 28, 1930, R.W. Woodruff Papers, 18191996. Emory University, Stuart A. Rose Manuscript Archives and Rare Book Library, Atlanta GA 30322. In the earlier version of this paper, we cited \$1.11 as the new cost, quoting from Allen (1994, p. 196). We, however, discovered that Allen’s figure was mistaken, after locating a copy of the above memo.

${ }^{20} 1 \mathrm{Lb}$ of Merchandise No. 5 was needed to make 16-Gallons of Coca-Cola syrup, and thus the cost of Merchandise No. 5 that

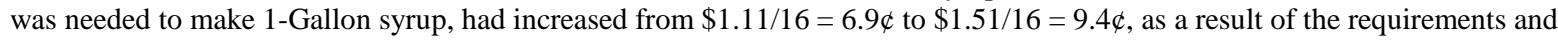
the conditions the Porter Bill set. 
of the Company's gross sales, net profits, and expenses, the added cost amounted to about $0.20 \%, 0.60 \%$, and $0.90 \%$, respectively. These figures do not seem as large, although we should emphasize that they should be interpreted as the lower bound of the true perceived cost of breaching the implicit contract by adjusting the drink’s quality, as viewed by the Company management.

\section{A brief history of New Coke}

Having presented evidence on the perceived costs of breaching the implicit contract's quality clause based on what the Coca-Cola Company incurred to avoid its breach, we now turn our attention to evidence on the realized costs when the Company actually breached the implicit contract by introducing "New Coke” in 1985. We begin with a brief overview of the development and introduction of the now-infamous New Coke.

In the late 1970s and early 1980s, Coca-Cola’s market share was falling while Pepsi's was on the rise. These trends were contemporaneous to, and perhaps reinforced by, PepsiCo's "Pepsi Challenge” national marketing campaign of blind taste tests conducted in public areas. ${ }^{21}()$ According to figures from the Coca-Cola Company, the Coke's market share, which stood on 60 percent after WWII, was down to only 22 percent by 1984; Pepsi’s market share that year stood on 18 percent, on the verge of parity with Coca-Cola (Blanding, 2010, pp. 59-60). Even worse, the Company conducted its own blind taste tests with consumers and found that, indeed, they preferred Pepsi by margins as high as 10-15 points.

With management's blessing, Coca-Cola Company chemists began considering a reformulation of the Secret Formula. The research project was code-named "Project Kansas” and was the most secretive and elaborate endeavor ever undertaken by the Company. ${ }^{22}$ The Company undertook what became a two-year project in search of an improved formula that would beat Pepsi in blind tests. In the end, the Company chemists arrived at a new formula that differed in

\footnotetext{
${ }^{21}$ Some of these tests were filmed and became part of TV ads that captured the surprised faces of consumers who discovered that they had chosen Pepsi over Coke.

${ }^{22}$ According to the documents displayed at the Coca-Cola Museum in Atlanta, GA, only a handful of top executives of the company knew about the project. It was given the code-name "Kansas" because of a quote by William Allen White, the editor of The Emporia Gazette (Kansas), who for a picture taken for Life magazine on his $70^{\text {th }}$ birthday in 1938, asked that he be photographed beside a Coca-Cola dispenser at a local soda fountain, saying that Coca-Cola was "[...] the sublimated essence of all that America stands for [...] a decent thing, honestly made, universally distributed, conscientiously improved with the years." Source: Hollie (1985). In an undated confidential memo with the title "Negative Briefing: What if...?” which is displayed at the Coca-Cola Museum in Atlanta, GA, the goal of Project Kansas, its scope and boldness, are compared to not less than the Allied forces invasion of Europe in 1944!
} 
several ways from the original. ${ }^{23}$ The biggest difference was that the new formula contained less phosphoric acid to lessen the bite and give the drink a smoother taste. In addition, to replace the acidity lost by the reduction in phosphoric acid, the new formula contained more citric acid; this gave it more of a lemony aroma. It had more fructose, increasing the drink's sweetness. The amounts of caramel and caffeine were adjusted (in unspecified ways) and the amount of vanilla was reduced (also to lessen the bite). ${ }^{24}$ The secret blend of flavoring oils (“Merchandise No. 7x") was also adjusted. ${ }^{25}$ Finally, and importantly, Merchandise No. 5 was removed completely. Coca-Cola would henceforth contain neither of its namesakes: coca leaves and kola nuts.

The efforts appeared to have paid off: after an exhaustive battery of 190,000 blind taste tests, with respondents from every age group and every region of the country, the new formula was beating Pepsi by a margin of 6-8 points. The new formula was also beating the original Secret Formula in these taste tests.

New Coke was introduced with a huge fanfare in New York City on April 23, $1985 .{ }^{26}$ It was clear to consumers that the drink had undergone a substantial quality change. Indeed, they had been told so by the Coca-Cola Company.

\section{Market response to the New Coke: Cost of breaching the implicit contract}

In analyzing this change in the Secret Formula and the public response to it, we are able to offer the second, and this time more direct, evidence on the cost of breaching the implicit contract. Consider the cost of introducing New Coke. In addition to the direct cost of \$4 million (\$9.24 million in today’s prices) that the Coca-Cola Company spent on research, development, and blind taste-testing of the New Coke, the Company bottlers incurred a direct loss of \$30 million (about $\$ 69.3$ million in today’s prices) in the form of unsold New Coke inventories (Collins 1995). ${ }^{27}$

\footnotetext{
${ }^{23}$ The details of these differences and other general facts are drawn from Pendergrast (1993, pp. 354-371), Allen (1994, pp. 404415), Dubow and Childs (1998), and Blanding (2010, pp. 59-62).

${ }^{24}$ At the April 23, 1985 press conference where the New Coke was officially announced, the Company CEO, Roberto Goizueta described it as having "a rounder, bolder, more harmonious flavor" (Blanding, 2010, p. 61).

${ }^{25}$ Dubow and Childs (1998) speculate that this change involved an increase in the quantity of nutmeg.

${ }^{26}$ This was dubbed "Black Tuesday” by Secret Formula loyalists (Blanding 2010). At the April 23, 1985 press conference, Goizueta denied that the New Coke was sweeter than the old Coke, and suggested that Pepsi had nothing to do with it. This, however, did not convince the press or the public. It is worth noting that the April 23, 1985 New York Times, on p. D7 (as well as the Coca-Cola hometown's Atlanta Journal-Constitution and many other newspapers across the US) contained a full-page ad of Pepsi, declaring "The Other Guy Just Blinked.”

${ }^{27}$ See also the Atlanta Journal-The Atlanta Constitution, April 11, 1995, "New Coke's $10^{\text {th }}$ Anniversary: From Catastrophe to a Classic,” pp. D1, D8, and D9.
} 
However, these amounts were almost certainly of second order importance relative to the cost that the Coca-Cola Company incurred in terms of lost goodwill. In introducing New Coke, the Company breached the implicit contract it had established with its consumers: the New Coke was not "genuine," it was not "Real Thing."

It is not possible to measure directly or precisely the size of the cost of lost goodwill. To appreciate its likely magnitude, however, consider the following. New Coke was instantly hated by the vast majority of US consumers. Within a week of its introduction, over 1,000 phone calls were being received each day at the Company headquarters in Atlanta from consumers who were expressing shock, anger and outrage. By the beginning of June, the number of these calls increased to 8,000 a day. In addition, the company was bombarded by 40,000 letters of protest. By the end of the ordeal, more than 400,000 phone calls and letters were received. The letters, like the phone calls, were cries from the heart, making it clear that much more than a soft drink was involved. According to the Coca-Cola Company’s consulting psychologist, “[...] the emotions he heard were similar to those of grief-stricken parents mourning the death of favorite child."

The main complain in most of these letters and phone calls was the same: The Coca-Cola Company has betrayed them. Consider few examples: "Changing Coke is just like breaking the American dream, like not selling hot dogs at a ball game." "For years, I have been what every company strives for: a brand-loyal consumer. I have purchased at least two cartons of Coke a week for as long as I can remember... My 'reward' for this loyalty is having the rug pulled out from under me.” "Millions of dollars' worth of advertising cannot overcome years of conditioning, or in my case, generations. The old Coke is in the blood. Until you bring the old Coke back, I am going to drink R.C.”

People were even comparing the importance of Coca-Cola to that of the US Constitution and even God! "Would it be right to rewrite the Constitution? The Bible? To me, changing the Coke formula is of such a serious nature." "There are only two things in my life: God and Coca-Cola. Now you have taken one of those things away from me.” “Changing Coke is like God making the grass purple or putting toes on our ears or teeth on our knees." "My dearest Coke: You have betrayed me.” According to Allen (1994, p. 364), the Coca-Cola Company president Roberto Goizueta, after monitoring the consumer hotline and hearing the consumers’ complains, exasperatedly observed: "They talk as if Coca-Cola had just killed God.” 
Perhaps New Coke indeed tasted better in blind taste-tests. However, the fact was that many people did not want to like New Coke. They were unable to give it a fair chance, because they were angry at its very existence: "Blindfolded, people were consumers who wanted a new taste. Eyes open, they were Americans who felt betrayed by New Coke” (Allen 1994, p. 17). People took cans and bottles of the New Coke into streets and poured them down storm drains. Every single Company-staged “rolling out party” for New Coke was a complete failure, bringing only negative publicity and the public's demand to bring the old Coke back.

"Long before they had ever tasted a sip of it, millions of Americans decided they hated New Coke. All across the country and especially in the South, people responded to the formula change as if the Company had committed an act of parricide, killing off a beloved member of the family. The surge of emotion over old Coke defied all reason...In the media, writers and cartoonists treated the management of the Coca-Cola Company not as businessmen who were trying to improve a popular product, but as vandals who wanted to deface a national treasure...Protests sprouted up everywhere... In city after city, diehard Coke drinkers began stockpiling supplies of the old soft drink, often with local TV crews on hand to record the activity and showcase it on the nightly news” (Allen, 1994, p. $413-414){ }^{28}$

It is clear that the implicit cost in terms of lost goodwill dwarfed the $\$ 9.24$ million (in today’s prices) spent on research, development, and blind taste testing, and \$69.3 million (in today’s prices) lost due to unsold New Coke inventories.

\section{Breaching the implicit contract: What went wrong?}

One of the important issues in the context of implicit contracts is a vulnerability of the CocaCola Company to consumers' backlash in the case of implicit contract breach. This is important because it makes the contract credible by making it incentive compatible. Young and Levy (2014) demonstrate that the Company was indeed vulnerable to such a consumer backlash and that its management recognized this. The Company leadership knew that all three attributes of the product - price, quantity, and quality - had to be kept unaltered, as promised by the implicit

\footnotetext{
28 "Bottlers begged for the old drink back, since they were becoming social pariahs. In rural Alabama, a minister led his congregation in prayer for the local bottler's soul, which was undoubtedly destined for hell. In Marietta, Georgia, a woman assaulted a Coke delivery man with her umbrella as he tried to stock a supermarket shelf with New Coke. 'You bastard,' she screamed, 'you ruined it, it tastes like s---!' When a nearby Pepsi driver laughed, she spun around. 'You stay out of it! This is family business. Yours is worse than s---!’” Pendergrast (1993, p. 364).
} 
contract.

Beginning in 1920s, for example, the Coca-Cola Company was stressing in its ads both the $6.5 \mathrm{oz}$. quantity and $5 \$$ price as something that consumers expected and could count on. ${ }^{29}$ Similarly, upon becoming president of Coca-Cola, Robert Woodruff “established several guidelines [among which was that] he would never tamper with the quality of the product” [our emphasis], (Kahn, 1969, p. 74). ${ }^{30}$ The long-running campaign depicting Coca-Cola as the "Real Thing” was reflecting the Company's continued effort to communicate that commitment to the general public. ${ }^{31}$

Similarly, the Coca-Cola Company management recognized early on the importance of protecting and preserving its consumer goodwill. ${ }^{32}$ For example, the 1924 annual report of the Company stated: “All of our equipment might be replaced more easily than could our goodwill, which has been cultivated through 38 years of consistent effort.”33 The Company leadership viewed the maintenance of the implicit contract as a key to the accumulation and maintenance of consumer goodwill.

In light of these insights and understandings of the Coca-Cola Company leadership, it was

\footnotetext{
29 “This glass increases sales,” stated a 1923 newspaper insert referring to 6.5oz glasses. The insert referred also to "The Right Price" of " 5 " " which "is the price people expect to pay for Coca-Cola, because it is established by years of custom" [our emphasis]. Source: Trade Paper Insert, reproduced, Coca-Cola Company Archive, Atlanta, GA. As another example, in a correspondence addressed to its salesmen concerning the need to continue the nickel price strategy, the Company management asked: "How would one-third of your fountain customers feel if they were required to pay $100 \%$ more [than] they had been accustomed to paying...[?]” [our emphasis]. Source: Undated set of "Instructions for Salesmen in Campaign for Promoting 5థ Price on Coca-Cola,” Coca-Cola Company Archive, Atlanta, GA. The Company, fearful of the backlash as some retailers attempted in 1950 to raise the nickel price, conducted a survey of consumers' reaction to such price hike attempts. According to the findings of one such survey, "At first, the public bought up all available Coca-Cola at the old price. As soon as the supply was depleted, [a] boycott was imposed." “Typical consumer comments” included: "Buy a Coke? Not me. Haven’t had one since the price went up. I'll wait until it comes down.” “They will be sorry. I haven’t had a Coke all week and I won’t until it sells for a nickel.” "The bastards! No one buys Coke now.” "Coke will be back to a nickel soon. Just wait and see.” Source: Price Situation Survey, Alexandria, LA, 1950, Coca-Cola Company Archives, Atlanta, GA.

${ }^{30}$ According to the account of Robert Goizueta, who replaced Woodruff as the President of Coca-Cola, in one of his earliest meetings with Woodruff, "someone raised the question of using synthetic caffeine from mineral sources in Coca-Cola to save money. 'We only have one formula,' Woodruff replied stiffly, slamming the door on the subject” (Allen 1994, p. 392).

${ }^{31}$ Consider the following ad: "Some said: 'Raise the price to the retailer.' Some said: 'Lower the quality.' Some said: 'Cut the advertising appropriation.' That is the summary of advice we have received during the past year from people who knew how greatly our cost of making Coca-Cola has been advanced owing to extravagant rises in costs of all ingredients. We said: 'Price, quality and advertising will remain the same'... Then we would be mighty poor specimens if we tried to make the druggist carry the load of our increased costs by cutting down your profits on Coca-Cola. The burden is ours-we have gladly assumed it. As to lowering the quality of Coca-Cola-its quality is what has established it as a success.” Source: Drug Trade Journal (1916), reproduced in the Company's Advertising Copy Collection, 1916-1919, Vol. 5, 00502 ARS (Coca-Cola Company Archive). Similarly, a Company ad that appeared in many retail trade publications, reproduced in Coca-Cola Company's Advertising Copy Collection, 1942, 01724 ARS (Coca-Cola Company Archive) states: “There’s a seven-letter word for it: QUALITY... the quality of genuine goodness. That’s what your customers recognize in Coca-Cola...[I]t’s the real thing. 5థ. You trust its quality.” Again, the purpose was to convey to retailers the Company's promise to its consumers.

32 Tadelis (1999, p. 548, footnote 2) defines goodwill as the value of the firm's intangible assets, which includes the firm's brand name recognition and reputation. Accountants use balance sheet information to assess the value of these intangible assets as the difference between the firm's market value and the value of its net tangible assets.

${ }^{33}$ Source: Annual Report of the Coca-Cola Company, February 26, 1924, p. 4.
} 
remarkable that they abandoned the Secret Formula. Goizueta's decision to reformulate the 99year-old Coke was made based on blind taste-tests, with the hope of beating Pepsi in their fight for the market share. What the Coca-Cola Company management did not take into account was the America’s emotional attachment to what "Coca-Cola” stood for: continuation, stability, childhood memories. It was not the drink inside the bottle that mattered. It was the bottle, the label on it, the name “Coca-Cola,” and what it signified to America (Fischer, 1985).

As Blanding (2010) explains, they should have known better. ${ }^{34}$ When Coca-Cola was developing Diet Coke, the Company’s marketing people discovered that the word "Coke” was enough to drive sales. For example, "When they tested Tab against Pepsi, it lost by a 4 percent margin; when they poured the same drink into a Diet Coke can, however, it caused customer preference to jump 12 points” (p. 61). But that was attaching the term “Coke” to a different product alongside the original and still-available Coca-Cola. Replacing the old Coke with something different and labeling it “Coke”? Well, that was something entirely different.

Studies have confirmed this effect. For example Pierce (1987) and Pierce and Belke (1988) show that brand names and trademarks might exert greater influence over consumers' opinion then the products' taste. Based on their experiments, they reported that the product labels (rather than taste) influenced subjects' ratings of Coke and New Coke, depending on the subjects’ reported prior attitudes. The regular users of Coke ranked products that were labeled “Coke” higher than the products that were labeled "New Coke.” In contrast, subjects who did not drink Coke regularly showed a greater preference for the product labeled "New Coke.” These studies find that trademarks, brand names, labels and other similar commercial stimuli depend on the consumers' conditioning history. Furthermore, Lee et al. (1996) report that since Coca-Cola has been around for such a long time, consumers have developed a strong emotional attachment to the brand, and thus they do not like to see it changed. ${ }^{35}$ Although the consumers liked the New

\footnotetext{
${ }^{34}$ An episode related to a shortage of caramel during WW I, should have served as a lesson. In 1917, because of caramel shortage, "Howard [a Coca-Cola Company pharmacist] experimented with a caramel-free syrup and made up an otherwise ordinary one-gallon batch of Coca-Cola - it was straw-colored-to try out in taste tests. With blindfolds on, he reported, people found the flavor to be identical with regular Coca-Cola and perfectly acceptable, but "when the testers tried it with eyes open, the assertion was made that the uncolored product tasted different.” It was a parallel discovery to the one Company officials made with New Coke nearly seven decades later. Colorless Coke was scrapped” (Allen 1994, p. 89).

${ }^{35}$ Schindler (1992) reviews the market research methods the Coca-Cola Company used in the case of New Coke. He argues that the Company's miscalculation was a result of "the standard market research practice of considering focus groups to be only a form of preliminary research and not appreciating their unique ability to predict the effects of social influence” (p. 22). Similarly, Gelb and Gelb (1986), suggest that the "New Coke fiasco might have been avoided had market researchers concentrated more on consumers' emotional ties to the existing product. Coke drinkers believed that Coke stood for traditional values, as company ads had encouraged them to do, so they felt betrayed when the product changed radically overnight. Quantitative research often fails to uncover such fierce but unarticulated loyalties to the status quo” (p. 71).
} 
Coke in blind taste tests, it appears that the taste was not that important to them. It was the product, what it stood for, what it signified, that mattered. ${ }^{36}$

As Allen (1994) notes, "By creating an idea of the product that went far beyond its actual, utilitarian function - that of quenching thirst and providing a mild lift from sugar and caffeinethe [Coca-Cola] company had elevated Coca-Cola to an ethereal plane that had little to do with how it tasted or the size of the bottle it came in. The point wasn't to compete with other soft drinks or to insist that Coca-Cola was "better," but to hold tight to the precious illusion that Coca-Cola was something completely different, above and apart” (p. 237).

\section{Voice and exit under loyalty: Consumer reaction and Coca-Cola Classic}

A useful framework for understanding consumer reactions to New Coke and the Coca-Cola Company's subsequent re-introduction of the original product (as “Coca-Cola Classic”) is provided by Hirschman's (1970) classic work on voice, exit and loyalty. Hirschman explores the general case where:

"The performance of a firm or an organization is assumed to be subject to deterioration for unspecified, random causes which are neither so compelling nor so durable as to prevent a return to previous performance levels, provided managers direct their attention and energy to that task” (pp. 3-4).

The above provides an apt characterization of the Coca-Cola Company's breach of the implicit contract with the introduction of New Coke. The violation of the quality clause of that implicit contract was at least potentially, "repairable lapse” (p. 1) on the part of the Company.

The management of a firm can be alerted to such a repairable lapse via two types of consumer reactions. First, consumers can stop buying the firm's goods and seek out one of its competitors to buy from instead. This is the exit option and it is an economist's default assumption regarding consumer reactions to deteriorations in quality. The availability of the exit option to consumers is the hallmark of a monopolistically competitive market where each firm is to some extent a price-

\footnotetext{
${ }^{36}$ It seems that the Coca-Cola Company has learned its lesson. On January 10, 2018, it was reported that the Coca-Cola Company has decided to revamp its Diet Coke line by introducing four new flavors, Diet Coke Ginger Lime, Diet Coke Feisty Cherry, Diet Coke Zesty Blood Orange, and Diet Coke Twisted Mango. Importantly, however, according to the report, "Diet Coke will still be available in its classic formulation” (our emphasis), Source: Jessica Dye, “Coca-Cola Hopes to Put Fizz Back in Diet Coke Sales with Brand Revamp,” Financial Times, January 10, 2008, https://www.ft.com/content/4e19e3f9-1297-3a82-a6f1-3a6367ce5da3, accessed January 31, 2018.
} 
and quality-maker; yet each also faces competition from firms that produce substitute goods. ${ }^{37}$

While exit is an economist's default assumption, Hirschman (1970) emphasizes that there is another reaction by which consumers can discipline a firm: voice. Voice can serve either as a substitute for or complement to exit. Consumers can voice their disappointment with a firm's performance, communicating their feelings individually or collectively to its management. Alternatively, they may communicate their frustration to the public - to "anyone who cares to listen” (p. 4) - to mobilize others to discipline the firm through their own exit or voice. ${ }^{38}$

As Hirschman (1970) emphasizes, exit is a market act: it is impersonal, usually taking place anonymously. Exit is also a binary decision: one either exits or does not. Alternatively, voice is a political act and it can range from a "faint grumbling to violent protest” (p. 16). The use of voice is typically personal, involving an expression of critical opinion to a firm’s management. Furthermore, increasing the frequency or intensity of that expression can make voice more effective, at least up to a point.

All else equal, voice will be exercised more often, or more intensely, when the exit option available to consumers is less appealing or simply unavailable. For example, when consumers have poor substitutes available from other firms, then they will tend to exercise their voice. In the extreme, when consumers are dealing with a monopoly then voice is their only option for disciplining a firm when its performance deteriorates. ${ }^{39}$ If a perfectly competitive firm experiences a quality deterioration, its consumers will likely exit and purchase the goods of its competitors. In a more realistic, intermediate case between monopoly and perfect competition, a mix of exit and voice reactions is likely to be observed. ${ }^{40}$

\footnotetext{
${ }^{37}$ The exit option, according to this model, leads to more efficient outcomes because the exit creates a pressure on the failing firm to get back on track and fix its failing, as otherwise the competitive forces will drive it out of the market altogether and thus eliminate the inefficiency. That is because the competitors - existing or newcomers—will step in to take up the failing firm's market share and hire its factors of production, leading to a better overall allocation of resources.

${ }^{38}$ Although Hirschman (1970) was the first to fully articulate the idea of voice as an alternative act or as a complementary act to the act of exit, it seems that other scholars have also noted the possibility of voice as an effective, although perhaps more cumbersome, alternative to exit. For example, Friedman (1962, p. 91), advocating the introduction of market mechanism into the public education states: "Parents could express their views about schools directly, by withdrawing their children from one school and sending them to another, to a much greater extent than is now possible. In general, they can now take this step only by changing their place of residence. For the rest, they can express their views only through cumbrous political channels.” Hirschman (1970) quotes Friedman to emphasize the economists' natural tendency/bias in favor of exit and against voice. ${ }^{39}$ Banerjee and Somanathan (2001) present a theoretical model where voice serves as a means of information aggregation within the organization.

40 The predictions of the theoretical model of Beard et al. (2015) and Gans, et al. (2017), are consistent with Hirschman's (1970) observations. Beard et al. (2015) develop a model of an experience good in which buyers discover after the purchase, ex post, that the good's quality is lower than they expected. Their model predicts that the greater is the competition, the smaller will be the number of consumers that will choose the option of voice, and the greater will be the number of consumers that will adopt the exit option. Similarly, Gans, et al. (2017) develop an equilibrium model of voice as a relational contract game, and show that the option of voice strategy will be chosen more often the more concentrated markets are.
} 
The case of Coca-Cola is clearly one of these intermediate cases, but one where the CocaCola Company had considerable market power. As we argue in section 3 above, Coca-Cola was potentially habit forming and, furthermore, the Company undertook extensive efforts to convince its consumers that ostensible close substitutes were not actually so: they were not "the real thing." This created substantial loyalty amongst Coca-Cola consumers, a factor that "holds exit at bay and activates voice,” because of the consumers' high switching costs (Hirschman 1970, p. 78). A consumer that is loyal to a firm will try to affect a reversal of a quality deterioration; furthermore, such a consumer "will often search for ways to make himself influential” (p. 77). Hirschman (1970, p. 80) observes that voice’s “effectiveness depends on the discovery of new ways of exerting influence and pressure towards recovery.” In light of this, one way to interpret consumers' references to "the American dream," "the US Constitution," and even "God” in their protestations is that they aimed to make them seem larger than themselves; to make their protests be perceived as universal by the Coca-Cola Company. ${ }^{41}$

According to Hirschman (1970), voice will be particularly effective in settings where there are few buyers or in settings where few buyers account for a substantial proportion of total sales. ${ }^{42}$ Voice can be used effectively also in the case of an expensive durable good, where consumers are often repeat-buyers. In the context of low cost non-durable goods, in contrast, most consumers will simply exit and switch to a substitute good.

According to these arguments, one would not expect to see the option of voice used in the case of Coca-Cola. Coca-Cola is a small, non-durable, and relatively low-cost consumer good. In addition, the marketplace offered numerous close substitute goods, including Pepsi, Dr. Paper, RC Cola, Dr. Brown, Double Cola, Fitz’s, Hansen’s, Gray’s, Jolly Good, Jolt Cola, Moxie, etc., as well as numerous private label substitutes, such as Kroger's Big K, Winn-Dixie’s Chek, etc.

In addition, Coca-Cola was not consumed by a small group of people. Rather, it was a national beverage, consumed across the US by millions of Americans (and by hundreds of millions around the globe). These attributes make Coca-Cola an unlikely candidate for voice. Instead, Coca-Cola seems to meet all the necessary criteria for the optimality of the exit choice. Brand loyalty, which is another important determinant of the option chosen, played a critical

\footnotetext{
${ }^{41}$ Kleshchelski and Vincent (2009) present a theoretical model in which a presence of switching costs leads to an establishment of long-term relationships between firms and their customers. In their setting, firms view customers as long-lived assets, leading to a tradeoff between increasing current profits and market share.

${ }^{42}$ In the model of Gans et al. (2017), voice is likely to be observed in concentrated markets because in such markets the value of retaining consumers is high to the firms.
} 
role in the case of Coca-Cola (Fisher, 1985). Loyal customers have high switching costs stemming from their attachment to the product, and therefore, they will be amongst the nonexiting, vocal protesters.

Indeed, as discussed above, in the case of Coca-Cola, many of its consumers had a strong attachment to the drink, and thus, despite the existence of many substitutes, they chose the option of voice (which by itself is a costly activity) rather than switching to one of the substitutes. The various acts of protest undertaken by a large number of loyal customers made the act of voice particularly effective. As Fischer (1985, p. 44) notes, "When the new Coke hit the shelves in the U.S. in April, consumers felt that the company had broken the first promise of branding: that what you get today will be what you got yesterday” (emphasis ours).

The effectiveness of voice was further strengthened by the fact that the threat of exit made by the voicing customers was credible: the New Coke sales never rose. To the contrary, many consumers chose the option of boycotting the Company. That is, they opted for a temporary exit, which in addition to demonstrating the consumer's determination and credibility, imposed huge cost on the Company in terms of revenues. ${ }^{43}$ As a result, the Company was losing market share on a daily basis. Thus, the effectiveness of the voice option the public adopted, was further strengthened by the availability of the exit option, credibility of which was demonstrated by the act of temporary exit many of them chose.

Given that the Coke drinkers opted for voice in large numbers suggests that loyalty played the central role. The implicit contract that the Americans had with Coca-Cola was only strengthened by this loyalty, to the point where it made the option of exit, i.e. the switching cost, too high and the option of voice worthwhile. The implicit contract, which included unchanging quality ("the real thing”) and unchanging price (“5 4 ”) assurances, formed a certain bond between Coca-Cola and America, turning Coca-Cola into something "bigger” than just a soft drink.

Thus, in the case of New Coke, the Coca-Cola Company’s consumers had been loyal and did clearly exercise both voice and (temporary) exit. (Regarding the latter, recall the \$69.3 million, in today's prices, of unsold New Coke inventories.) And their exercise of voice and exit were effective in moving the Company to repair its repairable lapse. Indeed, without much fanfare, on July 11, 1985, in Atlanta, GA, the Company announced the return of the original Coke under the

\footnotetext{
${ }^{43}$ Hirschman (1970) defines boycott as a hybrid of exit and voice. Many of the customers that chose this option were amongst those who were voicing their dissatisfaction by calling, and writing to the Coca-Cola Company headquarters.
} 
name, “Coca-Cola Classic.” Don Keough, Vice President for Operations, summarized the lesson the Company learned from the century’s biggest blunder: “There is a twist to this story which will please every humanist and will probably have the Harvard professors puzzling for years. The simple fact is that all the time and money and skill poured into consumer research on the New Coca-Cola could not measure or reveal the deep and abiding emotional attachment to original Coca-Cola felt by so many people... The passion for original Coca-Cola-and that is the word for it: passion — was something that caught us by surprise... It is a wonderful American mystery, a lovely American enigma, and you cannot measure it any more than you can measure love, pride, or patriotism” (Allen, 1994, p. 416).

As argued above in section 6, the cost in terms of lost goodwill almost certainly dwarfed the, in today’s prices, \$9.24 million in R\&D and \$69.3 million in unsold inventories. That implies that voice and exit were complementary, but the former was considerably more important in moving the Coca-Cola Company to restore the Secret Formula. Consumers' loyalty led them to exercise both exit and voice in complementary fashion: they refused to buy New Coke and complained about it vociferously and bitterly, to anyone who cared to listen.

\section{Conclusion}

In this paper we offer empirical evidence on the magnitude of the cost of breaching an implicit contract in the market for Coca-Cola. We offer two types of evidence. One is indirect while the other is more direct.

The indirect evidence is based on the argument that if the Coca-Cola Company chose to pay a permanently higher marginal cost of production over one-time higher fixed cost to avert a change in the quality of Coca-Cola, then we can interpret the increase in the marginal cost as a lower bound of the true cost of breaching the implicit contract, as perceived by the Company.

The direct evidence is based on the analysis of the market reaction that followed the CocaCola Company's decision to alter the century-old Secret Formula, by eliminating the original Coke that Americans, along with the rest of the world, have been drinking for decades, and replacing it with the New Coke. We analyze the reasons for this decision and discuss the specific changes the Company implemented in the Secret Formula.

Ex post, it seems that the decision was not very wise, but ex ante it seemed to make sense to everyone involved. Even “the Boss” himself, Robert W. Woodruff (who swore never to alter the 
Secret Formula), gave the Company his "approval” to go ahead with the formula change.

It is possible however that inside, Woodruff was not completely sure about the radical move. This speculation is based on the observation that the Coca-Cola Company's decision to eliminate the original Coke and replace it with the New Coke may have Granger-caused Woodruff's death. Consider Pendergrast's (1993, p. 356) account based on his interview with Roberto Goizueta:

“Over the Christmas holidays of 1984, Roberto Goizueta, Don Keough, Brian Dyson, and Ike Herbert decided unanimously to change the world's best known product just short of its hundredth anniversary. First, however, they needed the Boss’s [Robert W. Woodruff's] blessing... On New Year's Day, Goizueta made the pilgrimage down to Ichauway. Alone with the old man, the Cuban CEO kept his story short and simple, reviewing the rationale for the formula modification—dwindling market share coupled with a superior new taste. In the end, Woodruff agreed, convinced that Goizueta was right and that tastes had shifted. It was more important that Coca-Cola be the best-tasting drink in the world than to cling to an outmoded formula. Strangely, though, the Boss couldn't eat his dinner that night. The next morning, he refused his customary huge breakfast. An era was ending, and Robert Woodruff would end his life with it. The Boss demonstrated the remarkable power of his will one last time. He simply stopped eating."

Woodruff died on March 7, 1985 at the age of 95, about a month before the official introduction of the New Coke. Had he lived three more months, he would see that the New Coke was perhaps (as some have argued) one of the smartest marketing stunts ever employed by a corporation, and that "the real thing" is still here.

While we recognize that this is a case study, we believe that it is an important case study because the Coca-Cola Company is one of the largest, most successful and recognized products, and among the most valuable brands, in the world. Based on our findings, we can speculate that similar implicit contracts might exist in the context of other consumer products characterized by loyal customers with strong attachment. In such cases, the cost of breaching the implicit contract might be as substantial as in the case of Coca-Cola. Future studies could explore the existence of such implicit contracts.

Modern internet technologies and the new social media outlets are dramatically reducing the cost of voice while making it potentially far more effective, primarily because of the speed and the breadth in which voice can spread through the internet and through social media outlets. This 
suggests that in future, we shall see a greater use of voice in similar circumstances. The increased availability of the social media data (e.g., tweets data used by Gans, et al 2017) will offer new avenues and opportunities for future research on implicit contracts, and on voice, exit, and loyalty. 


\section{References}

Allen, Frederick (1994), Secret Formula: How Brilliant Marketing and Relentless Salesmanship Made Coca-Cola the Best-Known Product in the World (New York, NY: Harper Business).

Álvarez, Luis J., Emmanuel Dhyne, Marco Hoeberichts, Claudia Kwapil, Hervé Le Bihan, Patrick Lünnemann, Fernando Martins, Roberto Sabbatini, Harald Stahl, Philip Vermeulen, and Jouko Vilmunen (2006), "Sticky Prices in the Euro Area,” Journal of the European Economic Association 4, 575-584.

Amirault, David, Carolyn Kwan, and Gordon Wilkinson (2004), “A Survey of the Price-Setting Behavior of Canadian Companies,” Bank of Canada Review (Winter 2004-2005), 29-40.

Anderson, Eric T. and Duncan I. Simester (2010), "Price Stickiness and Customer Antagonism," Quarterly Journal of Economics 125(2), 729-765.

Apel, M., R. Friberg,, and K. Hallsten, K. (2005), "Microfoundations of Macroeconomic Price Adjustment: Survey Evidence from Swedish Firms,” Journal of Money, Credit and Banking 37, 313-338.

Baker, George, Robert Gibbons, and Kevin J. Murphy (2002), "Relational Contracts and the Theory of the Firm,” Quarterly Journal of Economics 117, 39-84.

Ball, Laurence and David Romer (2003), “Inflation and the Informativeness of Prices,” Journal of Money, Credit, and Banking 35, 177-196.

Banerjee, Abhijit and Rohini Somanathan (2001), “A Simple Model of Voice,” Quarterly Journal of Economics 116, 189-227.

Beard, Randolph, Jeffrey Macher, and John Mayo (2015) “Can You Hear Me Now? Exit, Voice and Loyalty under Increasing Competition,” Journal of Law and Economics 58(3), 717-745.

Bils, Mark (1989), “Pricing in a Customer Market,” Quarterly Journal of Economics 104, 699_ 718.

Blanding, Michael (2010), The Coke Machine: the Dirty Truth behind the World's Favorite Soft Drink (New York, NY: Avery-Penguin Group).

Blinder, A.S. (1991), "Why Are Prices Sticky? Preliminary Results from an Interview Study," American Economic Review 81(2), 89-100.

Blinder, A.S. (1994), “On Sticky Prices: Academic Theories Meet the Real World,” in N.G. Mankiw, Ed., Monetary Policy (Chicago, IL: NBER and the University of Chicago Press), pp. 117-154.

Blinder, A.S., E.D. Canetti, D.E. Lebow and J.B. Rudd (1998), Asking about Prices (New York, NY: Russell-Sage Foundation).

Cabral, Luís (2000), “Stretching Firm and Brand Reputation,” Rand Journal of Economics 31, 658-673.

Caplin, Andrew (1993), “Individual Inertia and Aggregate Dynamics,” in Optimal Pricing, Inflation, and the Cost of Price Adjustment, E. Sheshinski and Y. Weiss, eds. (Cambridge, MA: The MIT Press), pp. 19-45.

Carlton, Dennis (1979), “Contracts, Price Rigidity, and Market Equilibrium,” Journal of Political Economy 87(5), 1034-1062.

Carlton, Dennis (1989), “The Theory and the Facts of How Markets Clear: Is Industrial Organization Valuable for Understanding Macroeconomics?” in Richard Schmalensee and Robert D. Willig (Eds.), Handbook of Industrial Organization, Volume 1 (Amsterdam: North Holland, 1989), pp. 909-946.

Collins, Glenn (1995), “Ten Years Later, Coca-Cola Laughs at 'New Coke’,” New York Times, April 11, 1995, Business Day Section, p. C4. 
Dhyne, Emmanuel, Luis J. Álvarez, Hervé Le Bihan, Giovanni Veronese, Daniel Dias, Johannes Hoffmann, Nicole Jonker, Patrick Lünnemann, Fabio Rumler, and Jouko Vilmunen (2006), "Price Changes in the Euro Area and the United States: Some Facts from Individual Consumer Price Data,” Journal of Economic Perspectives 20, 171-192.

Dubow, J. and N. Childs (1998), "New Coke, Mixture Perception, and the Flavor Balance Hypothesis,” Journal of Business Research 43, 147-155.

Fabiani, Silvia, Martine Druant, Ignacio Hernando, Claudia Kwapil, Bettina Landau, Claire Loupias, Fernando Martins, Thomas Y. Mathä, Roberto Sabbatini, Harald Stahl and Ad C. J. Stokman (2005), “The Pricing Behaviour of Firms in the Euro Area: New Survey Evidence,” ECB Working Paper Number 535.

Fabiani, S., C. Loupias, F. Martins, and R. Sabbatini (2007), “Introduction,” in: Fabiani et al. (Eds.), Pricing Decisions in the Euro Area-How Firms Set Prices and Why (New York, NY: Oxford University Press).

Fehr, Ernst and Simon Gächter (2000), "Fairness and Retaliation: the Economics of Reciprocity,” Journal of Economic Perspectives 14(3), 159-181.

Fisher, Anne B. (1985), “Coke’s Brand Loyalty Lesson,” Fortune, August 1985, 44-46.

Friedman, Milton (1962), Capitalism and Freedom (Chicago, IL: University of Chicago Press).

Gans, Joshua S., Avi Goldfarb, and Mara Lederman (2017), “Exit, Tweets, and Loyalty,” NBER Working Paper, No. 23046.

Gelb, B. and G. Gelb (1986), “New Coke’s Fizzle - Lessons for the Rest of Us,” Sloan Management. Review 28(1), 71-76.

Godley, Andrew C. (2013), "Entrepreneurial Opportunities, Implicit Contracts, and Market Making for Complex Consumer Goods,” Strategic Entrepreneurship Journal 7(4), 373-287.

Gordon, Robert (1981), “Output Fluctuation and Gradual Price Adjustment,” Journal of Economic Literature 19, 493-530.

Gordon, Robert (1990), “What Is New-Keynesian Economics?” Journal of Economic Literature 28, 1115-1171.

Gottfries, N. (1991), “Customer Markets, Credit Market, Imperfections and Real Price Rigidity,” Economica 58, 317-323.

Greenslade, Jennifer and Miles Parker (2008), "Price-Setting Behaviour in the United Kingdom,” Bank of England Quarterly Bulletin (Q4), 404-415.

Hall, S., M. Walsh, and A. Yates (1996), “How Do U.K. Companies Set Prices?” Bank of England Quarterly Bulletin, May, 180-192.

Hall, S., M. Walsh, and A. Yates (2000), “Are UK Companies’ Prices Sticky?” Oxford Economic Papers 52(3), 425-446.

Helper, Susan, and Rebecca Henderson (2014), “Management Practices, Relational Contracts, and the Decline of General Motors,” Journal of Economic Perspectives 28(1), 49-72.

Hirschman, Albert (1970), Exit, Voice, and Loyalty: Responses to Decline in Firms, Organizations, and States (Cambridge, MA: Harvard University Press).

Hollie, Pamela G. (1985), “Fans of ‘Old’ Coke Wouldn’t Give Up,” New York Times, July 12, 1985. Available at: http://www.nytimes.com/1985/07/12/business/fans-of-old-coke-wouldn-tgive-up.html, accessed on December 15, 2013.

Horowitz, Roger (2016), Kosher USA: How Coke Became Kosher and Other Tales of Modern Food (New York, NY: Columbia University Press).

Kahn, E.J., Jr. (1969), Robert Winship Woodruff (Atlanta, GA: The Coca-Cola Company). 
Kahneman, Daniel, Jack Knetsch, and Richard Thaler (1986), "Fairness as a Constraint on Profit Seeking: Entitlements in the Market,” American Economic Review 76, 728-741.

Klein, Benjamin and Keith B. Leffler (1981), “The Role of Market Forces in Assuring Contractual Performance,” Journal of Political Economy 89, 615-641.

Klenow, Pete and B.A. Malin (2011), “Microeconomic Evidence on Price-Setting,” in B. Friedman and M. Woodford (Eds.), Handbook of Monetary Economics (New York, NY: North Holland), pp. 231-284.

Kleshchelski, Isaac, and Nicolas Vincent (2009), “Market Share and Price Rigidity,” Journal of Monetary Economics 56 (2009) 344-352.

Knotek, Edward S., II (2008), “Convenient Prices, Currency and Nominal Rigidity: Theory with Evidence from Newspaper Prices,” Journal of Monetary Economics 55, 1303-1316.

Knotek, Edward S., II (2011), "Convenient Prices and Price Rigidity: Cross-Section Evidence,” Review of Economics and Statistics 93(3), 1076-1086.

Leahy, John (2011), “A Survey of New Keynesian Theories of Aggregate Supply and their Relation to Industrial Organization,” Journal of Money, Credit and Banking 43, 87-110.

Lee, M., J. Lee and W. Kamakura (1996), “Consumer Evaluations of Line Extensions: a Conjoint Analysis,” Advances in Consumer Research 23, 289-295.

Levin, Jonathan (2003), "Relational Incentive Contracts,” American Economic Review 93, 835847.

Levy, Daniel and Frank Smets (2010), "Price Setting and Price Adjustment in Some European Union Countries: Introduction to the Special Issue,” Managerial and Decision Economics 31, 63-66.

Levy, Daniel and Andrew T. Young (2004), “'The Real Thing:' Nominal Price Rigidity of the Nickel Coke, 1886-1959,” Journal of Money Credit and Banking 36, 765-799.

Nakamura, Emi and Jón Steinsson (2011), "Price Setting in Forward-Looking Customer Markets,” Journal of Monetary Economics 58, 220-233.

Okun, Arthur (1981), Prices and Quantities: a Macroeconomic Analysis (Washington, DC: The Brookings Institution).

Paciello, Luigi, Andrea Pozzi, and Nicholas Trachter (2019), "Price Dynamics with Customer Markets,” International Economic Review 60(1), 1-34.

Pendergrast, Mark (1993), For God, Country and Coca-Cola: The Unauthorized Biography of the Great American Soft Drink and the Company that Makes It (New York, NY: Simon and Schuster).

Phelps, E. and S. Winter (1970), “Optimal Price Policy under Atomistic Competition,” in: Phelps, E. (Ed.), Microeconomic Foundations of Employment and Inflation Theory (New York, New York: Norton).

Pierce, W. David (1987), "Which Coke Is It? Social Influence in the Marketplace,” Psychological Reports 60, 279-286.

Pierce, W. David and Terry W. Belke (1988), "Stimulus Control of Consumer Opinion by Brand Names: a Social Conditioning Analysis,” Psychological Record 38, 227-236.

Romer, David (1993), “The New Keynesian Synthesis,” Journal of Economic Perspectives 7, $5-22$.

Rotemberg, Julio (1987), “The New Keynesian Microfoundations,” NBER Macroeconomics Annual, 69-104.

Rotemberg, Julio (2005) "Customer Anger at Price Increases, Changes in the Frequency of Price Adjustment and Monetary Policy,” Journal of Monetary Economics 52, 829-852. 
Rotemberg, Julio (2011), “Fair Pricing,” Journal of the European Economic Association 9, 952-981.

Schaeffer, R., and W. Bateman (1985) “The Formula for Coca-Cola: The Old ... The New,” The Cola Call 4-6 (Coca-Cola Company Archives).

Schindler, Robert (1992), "The Real Lesson of New Coke: the Value of Focus Groups for Predicting the Effects of Social Influence,” Marketing Research 4, 22-27.

Shapiro, Carl (1983), "Premiums for High Quality Products as Returns to Reputations," Quarterly Journal of Economics 98, 659-680.

Small, Ian, and Tony Yates (1999), "What Makes Prices Sticky? Some Survey Evidence for the United Kingdom,” Bank of England Quarterly Bulletin (August), 262-271.

Snir, A., H. Chen, and D. Levy (2018), “Zero-Ending Prices, Cognition, and Price Rigidity,” manuscript.

Söderberg, Johan (2011), “Customer Markets and the Welfare Effects of Monetary Policy,” Journal of Monetary Economics 58, 206-219.

Tadelis, Steven (1999), “What's in a Name? Reputation as a Tradeable Asset,” American Economic Review 89(3), 548-563.

Telser, L.G. (1964), “Advertising and Competition,” Journal of Political Economy 72, 537-562.

Telser, L.G. (1980), “A Theory of Self-Enforcing Agreements,” Journal of Business 53, 27-44.

Tyran, Jean-Robert and Dirk Engelman (2005), "To Buy or Not to Buy? An Experimental Study of Consumer Boycotts in Retail Markets,” Economica 72, 1-16.

Verhelst, Benjamin and Dirk Van den Poel (2012), "Implicit Contracts and Price Stickiness: Evidence from Customer-Level Scanner Data,” Working Paper No. 2012/776, Faculty of Economics, Ghent University.

Weiss, Yoram (1993), "Inflation and Price Adjustment: a Survey of Findings from Micro-Data," in Optimal Pricing, Inflation, and the Cost of Price Adjustment, E. Sheshinski and Y. Weiss, eds. (Cambridge, MA: The MIT Press), pp. 3-17.

Willis, Jonathan (2003), "Implications of Structural Changes in the U.S. Economy for Pricing Behavior and Inflation Dynamics,” Federal Reserve Bank of Kansas City Review $1^{\text {st }}$ Quarter, 5-27.

Wolman, Alex (2007), “The Frequency and Costs of Individual Price Adjustment: A Survey,” Managerial and Decision Economics 28, 531-552.

Young, Andrew and Daniel Levy (2014), “Explicit Evidence of an Implicit Contract,” Journal of Law, Economics, \& Organization 30(4), 804-832. 
Figure 1. Retail Price of 6 1/2 oz Coca-Cola vs Retail Prices of Other Foodstuff, 1890-1957

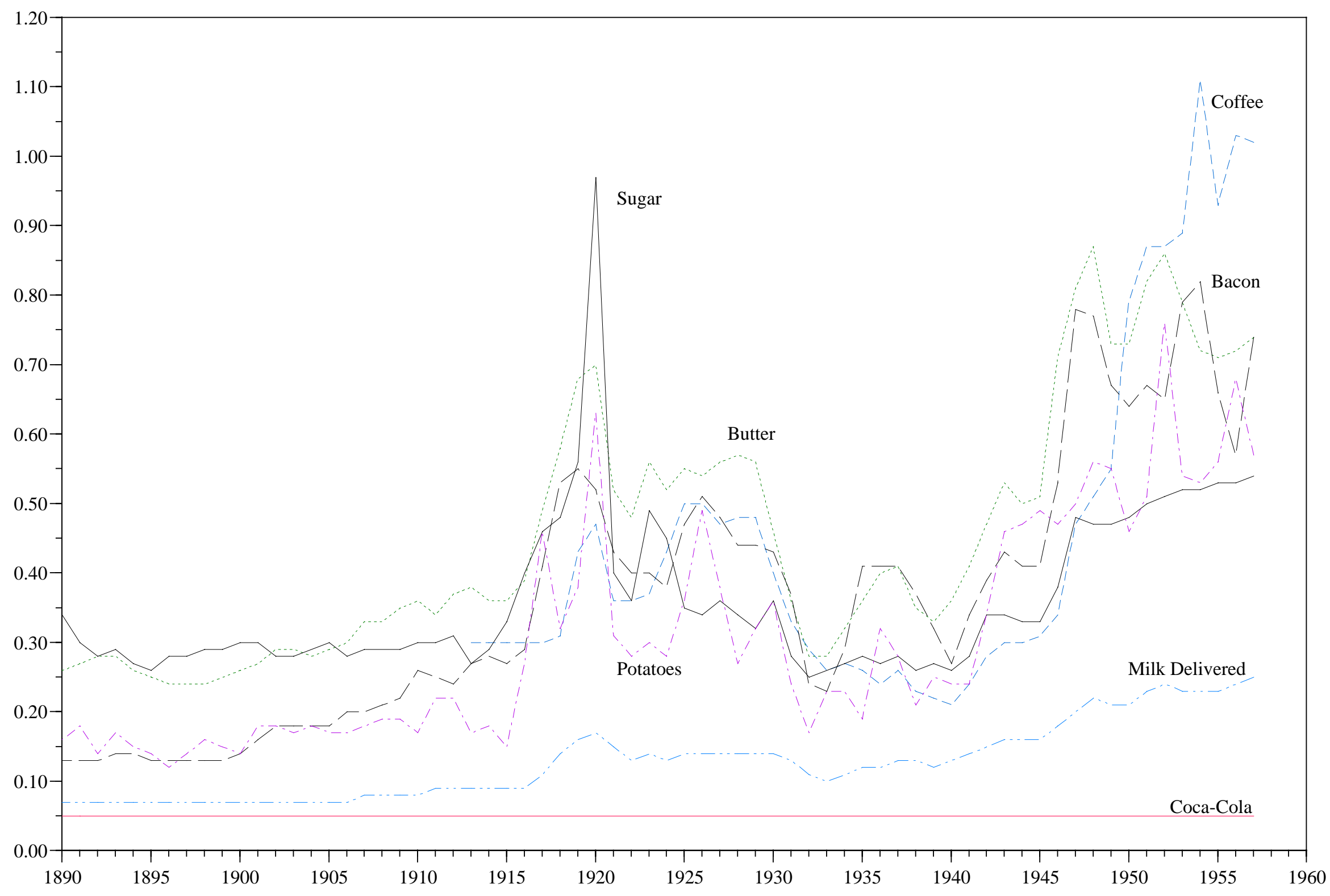

Measurement Units: Coca-Cola (\$/6.5oz), Milk Delivered (\$/Qt), Coffee $(\$ / L b)$, Butter $(\$ / L b)$, Sugar $(\$ / L b)$, Bacon $(\$ / L b)$, and Potatoes $(\$ / 10 \mathrm{Lb})$. Source: Historical Statistics of the United States: Colonial Times to 1970, 1989 Edition.

Source: Levy and Young (2004), p. 770. 
Figure 2. Coca-Cola Timeline, 1886-1959

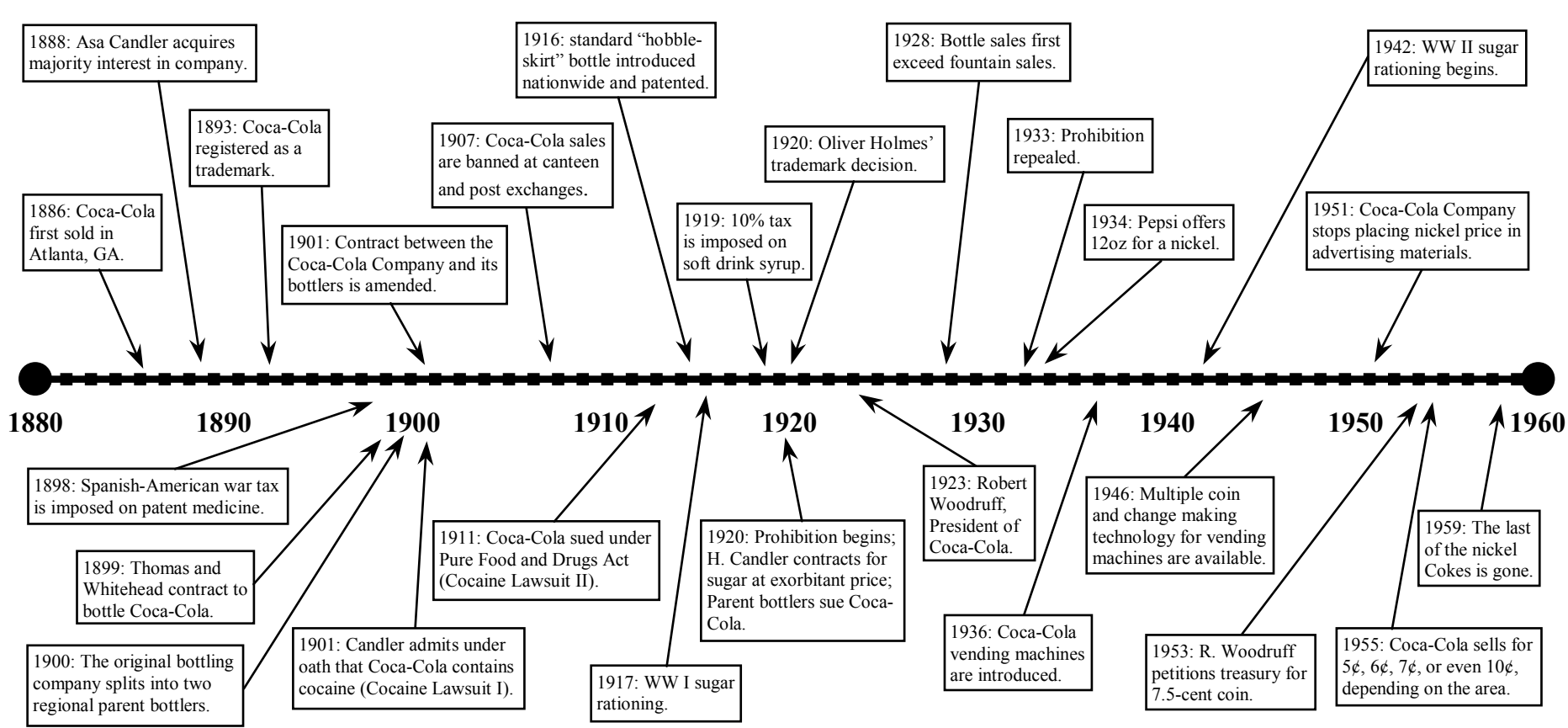

Source: Levy and Young (2004), p. 772 
Figure 3. Total gallons of Coca-Cola syrup sold, US and Foreign, 1890-1939

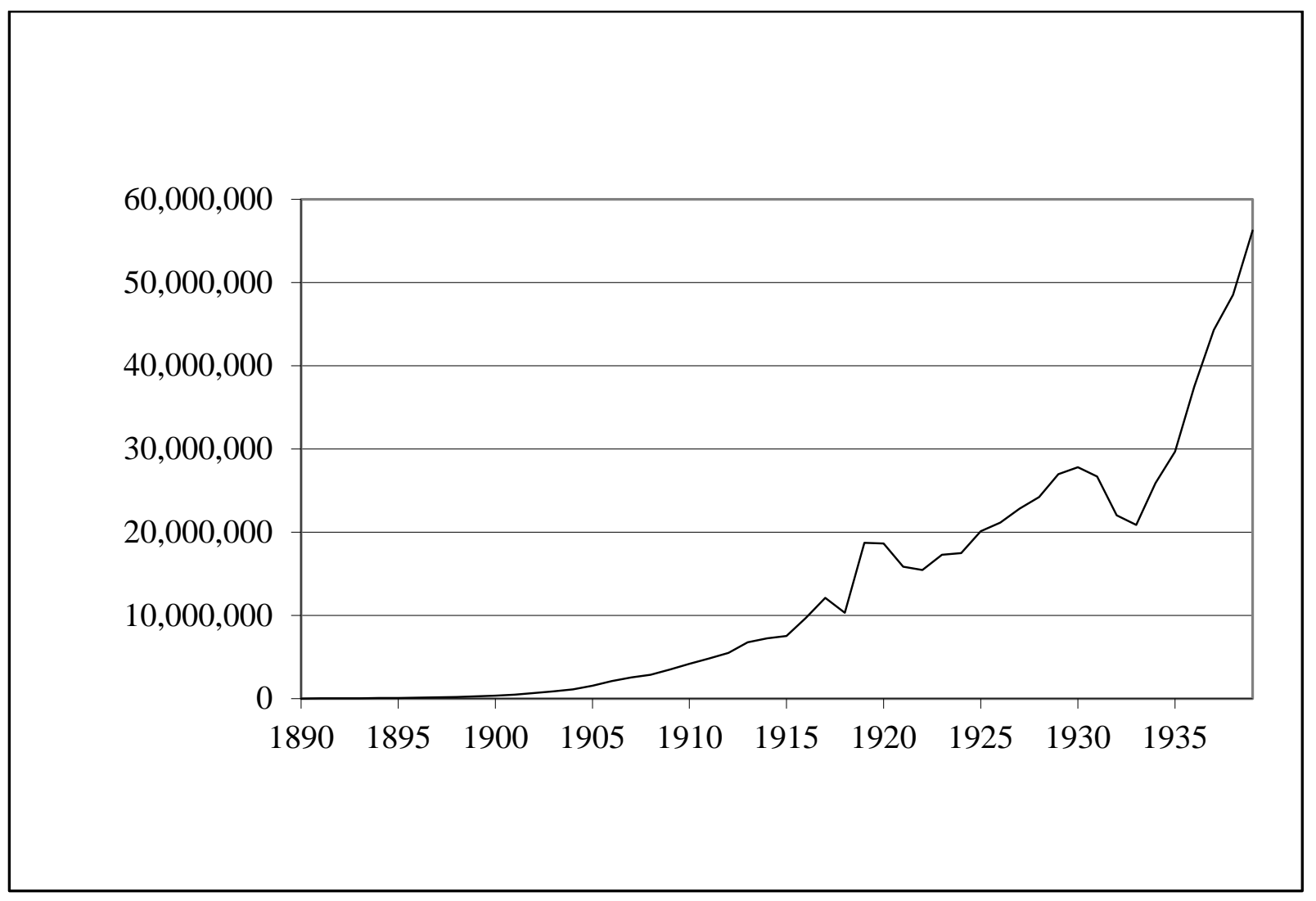

Source: "Sales 1886 through 1939," Internal Document, Coca-Cola Company Archive. 
Table 1. The increase in the marginal cost of producing Merchandise No. 5 as a result of the 1930 Porter Bill

\begin{tabular}{|l|c|c|c|c|c|c|c|}
\hline & $\begin{array}{c}\text { Gallons of } \\
\text { syrup sold }\end{array}$ & $\begin{array}{c}\text { Merch. } \\
\text { No. 5 } \\
\text { needed } \\
\text { (Lb.) }\end{array}$ & $\begin{array}{c}\text { Added cost } \\
\text { of Merch. } \\
\text { No. 5 } \\
\text { (current \$) }\end{array}$ & $\begin{array}{c}\text { Added cost } \\
\text { of Merch. } \\
\text { No. 5 } \\
(2018 \text { \$) }\end{array}$ & $\begin{array}{c}\text { Added cost of } \\
\text { Merch. No. 5 } \\
\text { as a share of } \\
\text { gross sales (\%) }\end{array}$ & $\begin{array}{c}\text { Added cost of } \\
\text { Merch. No. 5 } \\
\text { as a share of } \\
\text { net profits (\%) }\end{array}$ & $\begin{array}{c}\text { Added cost of } \\
\text { Merch. No. 5 } \\
\text { as a share of } \\
\text { expenses (\%) }\end{array}$ \\
\hline 1931 & $26,679,998$ & 205,230 & 82,092 & $1,356,181$ & 0.20 & 0.59 & 0.91 \\
\hline 1932 & $22,022,817$ & 169,406 & 67,762 & $1,242,019$ & 0.20 & 0.63 & 0.73 \\
\hline 1933 & $20,891,971$ & 160,707 & 64,282 & $1,241,683$ & 0.20 & 0.59 & 0.74 \\
\hline 1934 & $25,909,268$ & 199,302 & 79,720 & $1,493,912$ & 0.20 & 0.56 & 0.82 \\
\hline 1935 & $29,670,098$ & 228,231 & 91,292 & $1,673,302$ & 0.20 & 0.58 & 0.85 \\
\hline 1936 & $37,478,577$ & 288,296 & 115,318 & $2,083,255$ & 0.20 & 0.57 & 0.90 \\
\hline 1937 & $44,293,110$ & 340,716 & 136,286 & $2,376,563$ & 0.19 & 0.59 & 0.90 \\
\hline 1938 & $48,508,414$ & 373,141 & 149,256 & $2,658,111$ & 0.19 & 0.58 & 0.85 \\
\hline 1939 & $56,248,702$ & 432,682 & 173,072 & $3,126,597$ & 0.19 & 0.60 & 0.87 \\
\hline
\end{tabular}

Notes:

1. Source: Coca-Cola Company Annual Reports for the corresponding years, and authors' calculations. For details, see section 4

2. The time series of gallon sales (see Figure 3) stops at 1939.

3. The net profit and expense figures for 1937 were not available, because the 1937 Annual Report was not found at the Coca-Cola Company archive). We therefore estimated them by interpolating their 1936 and 1938 values. 